\title{
What was the Purkinje doing while the monkey slept?
}

\author{
Mario Negrello ${ }^{1 *}$, Sungho Hong ${ }^{1}$, Erik De Schutter ${ }^{2}$ \\ From Nineteenth Annual Computational Neuroscience Meeting: CNS*2010 \\ San Antonio, TX, USA. 24-30 July 2010
}

Statements about the intrinsic firing modes available to the Purkinje neuron have recently found themselves amidst controversy $[1,2]$. While extracellular recordings from anesthetized animals and slices have shown a Purkinje neuron transitioning from up to down states respectively characterized by high frequency firing and longer quiescent periods - these observations have not been convincingly reproduced in awake and behaving animals. The fulcrum of the controversy is whether the Purkinje neuron possesses intrinsic bistability, and in that case, (1) what triggers the bistability and (2) whether functional consequences can be derived from this fact.

The debate has thus far focused on the putative differences between different model organisms (mice, rats, cats, primates) and experimental settings (slices, anesthetics), with observations varying according to the individual combinations.

Stepping towards a resolution of this issue we have collected recordings from Monkey's (Macacca Mulata) cerebellar flocculus, both with an awake and behaving monkey, and during sleep. We encounter a range of differences between the activities of the cerebellum in these two states. Specifically, we find that during sleep the Purkinje activity tends to resemble that of anesthetized animals or slices, with longer pauses (up to $500 \mathrm{~ms}$ ) related to complex spikes, and conversely, the absence of long pauses $(<<100 \mathrm{~ms})$ in the awake and behaving monkey, finding instead a conspicuous rhythmicity in the low gamma frequency $(40-80 \mathrm{~Hz})$. (Figure 1.)

It stands to reason that these two modes are related to the mossy fiber input, presumably much more coherent when the input volley relates to sensory and motor afferences (and cortical rhythms), and thereby suppressing the more intrinsic dynamics, which likely relate more closely to cerebellar cytoarchitectonics. By providing context to the seemingly discrepant observations, our conclusions appear both to justify, and thereby to approximate the opposing views, indicating moreover that to know how one type of activity becomes the

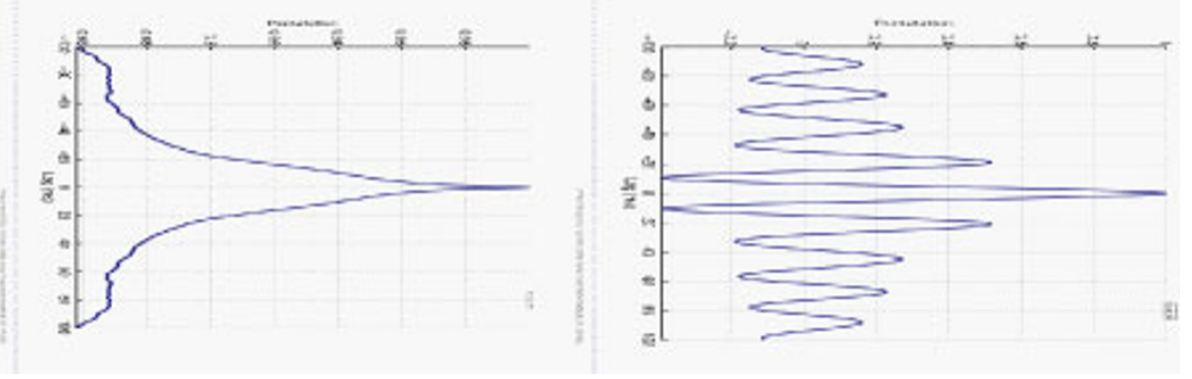

Figure 1 Autocorrelation of LFP channels. On the left, a sleeping monkey's LFP, on the right the LFP of the awake state.

* Correspondence: mnegrello@gmail.com

${ }^{1}$ Computational Neurocience Unit, OIST, Okinawa, Japan 
other one must regard the afferent activity of the waking state as responsible for the transition.

\section{Acknowledgements}

We thank A. Ignashchenkova and P. Thier for sharing their data with us.

\section{Author details}

${ }^{1}$ Computational Neurocience Unit, OIST, Okinawa, Japan. ${ }^{2}$ Theoretical

Neurocience, University of Antwerp, Antwerp, Belgium.

Published: 20 July 2010

\section{References}

1. Loewenstein, et al: Bistability of cerebellar Purkinje cells modulated by sensory stimulation. Nature Neuroscience 2005, 8(2):202-11.

2. Schonewille, et al: Purkinje cells in awake behaving animals operate at the upstate membrane potential. Nature Neuroscience 2006, 9(4):459-61, author reply 461.

doi:10.1186/1471-2202-11-S1-P9

Cite this article as: Negrello et al: What was the Purkinje doing while the monkey slept? BMC Neuroscience 2010 11(Suppl 1):P9.

\section{Submit your next manuscript to BioMed Central} and take full advantage of:

- Convenient online submission

- Thorough peer review

- No space constraints or color figure charges

- Immediate publication on acceptance

- Inclusion in PubMed, CAS, Scopus and Google Scholar

- Research which is freely available for redistribution

Submit your manuscript at www.biomedcentral.com/submit 